\title{
PEMERTAHANAN WARISAN BUDAYA WAYANG WONG GAYA YOGYAKARTA DAN KOMODIFIKASINYA UNTUK ATRAKSI WISATA DI KOTA YOGYAKARTA
}

\author{
${ }^{1}$ Prima Agustina M., ${ }^{2}$ Janianton Damanik, ${ }^{3}$ Heddy Shri Ahimsa-Putra \\ ${ }^{1}$ Fakultas Ilmu Budaya, Universitas Padjadjaran \\ ${ }^{2}$ Fakultas Ilmu Sosial dan Politik, Universitas Gadjah Mada \\ ${ }^{3}$ Fakultas Ilmu Budaya, Universitas Gadjah Mada \\ ${ }^{1}$ primamariamurti@gmail.com
}

\begin{abstract}
Abstrak
Wayang wong gaya Yogyakarta merupakan seni pertunjukan yang dasar gerakannya adalah tari klasik gaya Yogyakarta atau Joged Mataram. Masyarakat memanfaatkan warisan budaya wayang wong gaya Yogyakarta untuk atraksi wisata. Dalam perspektif kajian budaya, pemanfaatan tersebut merupakan industri budaya yang menuntut komodifikasi. Data penelitian dikumpulkan dari kepustakaan, wawancara dengan pakar wayang wong gaya Yogyakarta, dan pengamatan di lokasi pementasan, di tempat pembelajaran tari klasik di kota Yogyakarta. Hasil penelitian menunjukkan bahwa untuk tujuan atraksi wisata pementasan wayang wong gaya Yogyakarta mengalami perkembangan dan komodifikasi, tetapi masyarakat tetap mempertahankan aturan baku dari segi teknis tari dan penjiwaan dari para penarinya. Kata kunci: wayang wong, Yogyakarta, atraksi wisata, industri budaya, komodifikasi

\section{Abstract}

Wayang wong is an outstanding dance performance in Java. Yogyakarta's style means that the dance movement has its basic on Yogyakarta's classical court dance named Joged Mataram. People in Yogyakarta present the show of this intangible heritage as tourist attraction. Cultural studies acknowledge the practice as part of cultural industry which require its commodification. Datas are obtained out of field research and litterature study: interviews with experts of wayang wong Yogyakarta style, observations in some classical dance training societies in the city of Yogyakarta. The result indicate that transformation and commodification in wayang wong performance occured due to tourist attraction. Nevertheless, communities continue their effort to preserve the court classical dance standard in term of dance technicality and the highly controlled emotion of dancers expression.
\end{abstract}

Keywords: wayang wong, Yogyakarta, tourist attraction, cultural industry, commodification.

\section{PENDAHULUAN}

Wayang wong gaya Yogyakarta adalah pertunjukan drama tari berbasis tari klasik gaya Yogyakarta yang membawakan lakon dari kisah Ramayana, Mahabarata dan wayang purwa (Kadaryati, 2017). Pertunjukan wayang wong berkiblat pada wayang kulit mulai dari tata pentas, karakter tokoh, tata busana, dialog, iringan musik, tema cerita dan struktur pementasannya. Pemain wayang wong membutuhkan kemampuan menarikan tari Jawa klasik yang penuh aturan baku teknis tari (paugeran) dan penjiwaan yang kuat. 
Wayang wong gaya Yogyakarta sebagai tradisi pertunjukan berawal di kraton Yogyakarta pada saat Pangeran Mangkubumi atau Sultan Hamengku Buwono I (1755-1792) mendapat mandat dari Paku Buwono III untuk melestarikan tradisi Mataram (Soedarsono, 1989/1990; Kuswarsantyo, 2018) setelah palihan nagari yang memisahkan Mataram menjadi Kasunanan Surakarta dan Kasultanan Ngayogyakarta Hadiningrat akibat Perjanjian Giyanti pada tahun 1755. Dalam Perjanjian Jatisari tahun 1756 dibahas kelanjutan peninggalan budaya Mataram: wayang wong Mataraman menjadi wujud pemertahanan tradisi oleh Sultan Hamengku Buwono I. Sementara itu, kasunanan Surakarta lebih memilih untuk mengembangkan apa yang sudah ada.

Pertunjukan wayang wong gaya Yogyakarta saat ini sudah mengalami perubahan dan perkembangan, dari yang digelar di dalam kraton bagi para bangsawan dan pembesar Belanda pada masanya menjadi pertunjukan yang dapat dinikmati masyarakat luas termasuk wisatawan. Dalam perspektif pariwisata, wayang wong gaya Yogyakarta berpeluang sebagai atraksi karena memiliki kekhasan yang mencerminkan keluhuran budaya Jawa yang berasal dari kraton. Dari sisi kajian budaya, masyarakat memanfaatkan wayang wong gaya Yogyakarta menjadi atraksi wisata. Wayang wong gaya Yogyakarta pun menjadi bagian dari industri budaya. Masyarakat dalam penelitian ini adalah kelompok atau paguyuban tari yang mengajarkan tari klasik, sedangkan pemain wayang wong adalah penari karakter yang memiliki kemahiran tinggi dalam menarikan tari klasik dan menguasai dialog prosa liris dalam bahasa Jawa.

Atraksi dalam pariwisata budaya adalah inti yang fungsinya mendatangkan wisatawan sehingga ia harus berbeda dari atraksi yang mirip dengannya agar dapat bersaing. Fokus atraksi yang dicari adalah yang, menurut Reisinger dan Steiner, juga Olsen, menonjolkan keaslian orisinalitas dan keunikan (Damanik, 2013). Wayang wong gaya Yogyakarta unik, berbeda dari wayang wong lainnya terutama dari teknik gerakan penari. Pembanding terdekatnya adalah wayang wong gaya Surakarta. Menurut John Dewey, yang dikutip Soedarsono (1997), seni adalah suatu pengalaman pribadi. Demikian juga yang tercermin dari karakter kuat dan pengalaman diri Hamengku Buwono I selaku pimpinan militer di masa awal pemerintahannya ketika membangun Kasultanan Ngayogyakarta, yaitu serba lurus, langsung ke tujuan, dan bersahaja. Sifat batin tersebut terdapat dalam falsafah hidupnya (sawiji, greged, sengguh, ora mingkuh).

\section{METODE PENELITIAN}

Tulisan ini memaparkan hasil penelitian yang mengungkap pertunjukan wayang wong gaya Yogyakarta dalam industri budaya. Data dikumpulkan dengan melakukan studi pustaka dan wawancara dengan pengelola institusi pembelajaran tari klasik di Yogyakarta, juga pengamatan di lokasi, yaitu di Yayasan Pamulangan Beksa Sasminta Mardawa (YPBSM), Yayasan Siswa Among Beksa (YSAB) dan di Paguyuban Seni Suryo Kencono (PSSK), serta beberapa pementasan wayang wong selama tahun 2017 dan 2018 di kota Yogyakarta.

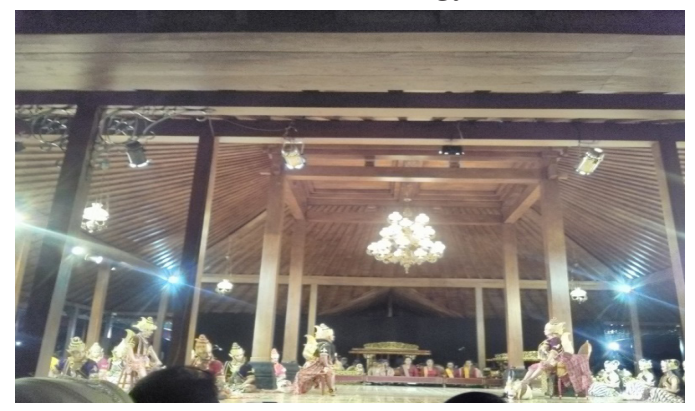

Gambar 1. Jejeran Sumber: penulis, 2017 


\section{HASIL DAN BAHASAN}

\subsection{Pemertahanan Keaslian Dan Keunikan Warisan Budaya Wayang Wong Gaya Yogyakarta}

Wayang wong merupakan sebuah genre tari, warisan budaya tak berwujud, yang awalnya dikenal sebagai wayang wong Mataraman karena bersumber dari tari gaya Mataraman. Istilah Mataraman mengacu pada sifat klasik yang kental dan tetap mempertahankan patokan baku, sedangkan Ngayogyakarta bersifat asal sudah tampak seperti gaya Yogya, artinya bukan Mataraman atau tidak terlalu klasik atau mengikuti aturan baku (Kuswarsantyo, 2018). Dalam definisi Pangeran Suryadiningrat, seorang pakar tari gaya Yogyakarta, tari adalah:

Ingkang kawastanan beksa inggih punika ebahing saranduning badan, katata pikantuk ungeling gending, jumbuhing pasemon lan pikajenganing joged

(terjemahan: yang disebut tari ialah gerak dari seluruh tubuh yang diiringi oleh bunyi gamelan yang diatur selaras dengan irama lagunya, cocoknya penjiwaan dengan maksud dan tari yang dibawakan)

Definisi tersebut melahirkan konsep dasar kesatuan dari gerak (wiraga), irama (wirama), dan ekspresi atau penjiwaan (wirasa) dalam tari.

Penari wayang wong gaya Yogyakarta dibedakan dalam karakter dasar yang dimainkannya, yaitu karakter putri, karakter putra gagah, dan karakter putra halus. Pemilihan penari pun disesuaikan dengan perawakannya. Pemeran karakter putra gagah dipilih dari penari berbadan besar dan tegap. Pemeran putra halus dan putri biasanya menggunakan penari berperawakan sedang. Zaman dahulu sampai masa Sultan Hamengku Buwono VIII, tari putri dan karakter pun dibawakan oleh remaja putra karena putri kraton tidak dibenarkan ikut muncul bersama banyak orang, terlebih lagi jika harus menari di hadapan banyak orang meskipun di dalam kraton (Soedarsono, 1997).

Dasar yang penting dikuasai oleh penari klasik gaya Yogyakarta ada tujuh, yaitu pandangan mata, gerak leher, sikap berdiri, gerakan pangkal paha, terbukanya posisi paha, penarikan jemari kaki ke atas, posisi tubuh merendah (Soedarsono, 2000).

\subsubsection{Pemertahanan Keaslian Wayang Wong Gaya Yogyakarta}

Istilah gaya Yogyakarta menunjukkan adanya gaya lain dalam wayang wong. Yang terdekat adalah gaya Surakarta, yang juga bersumber dari joged Mataraman. Gaya Yogyakarta sangat dipengaruhi sifat dan karakter Sultan Hamengku Buwono I. Wayang wong gaya Yogyakarta juga merepresentasikan jiwa dan semangat Sultan Hamengku Buwono I ketika mendirikan Kasultanan Yogyakarta. Beliau digambarkan sebagai orang yang teguh pendirian, tidak banyak tingkah dan memiliki citra sebagai pimpinan militer yang tangguh. Kebanyakan karya beliau dibawakan oleh penari pria dan memberi kesan maskulin yang kuat, seperti yang ditunjukkan oleh gerakan lengan dan kaki. Tema umumnya adalah perang. Beksan Lawung, misalnya, yang termasuk ke dalam tarian upacara pun menggambarkan latihan perang antara dua kelompok prajurit bersenjatakan tombak. Tarian ini pada awalnya dibawakan di Kepatihan yang biasa digunakan untuk resepsi pernikahan putra-putri Sultan. Karena Sultan biasanya tidak hadir di upacara yang diadakan di rumah Patih, maka sebagai pengganti yang bernilai sama dengan Sultan, dipergelarkan tari tersebut (Soedarsono, 1997).

Wayang wong gaya Yogyakarta tetap terjaga keasliannya karena aturan tari yang ada sejak zaman Sultan Hamengku Buwono I tidak mengalami banyak perubahan hingga sekarang. Secara umum, dalam pergelarannya ada adegan jejer, ada goro-goro, dan ada perpaduan antara unsur realis dan simbolis seperti yang terlihat pada karakter binatang (kijang bergerak dengan empat kaki, mbrangkang, burung garuda dibuat memiliki sayap yang dapat dikepak-kepakan dan dinaiki penari). 
Keteguhan jiwa Sultan Hamengku Buwono I ketika mulai membangun Kasultanan Ngayogyakarta juga meresap dalam joged Mataram. Ada empat persyaratan pokok yang tersirat dalam joged Mataram, yaitu sawiji, greged, sengguh, dan ora mingkuh. Penari tari klasik dan wayang wong yang berkualitas akan menerapkan falsafah Sultan Hamengku Buwono I tersebut, dan itu akan tampak dari penjiwaan para penari ketika berada di pentas. Sawiji adalah konsentrasi, yang dilakukan total meskipun di atas panggung terjadi hal-hal yang tidak diinginkan, karena begitu seorang pemain wayang wong berada di atas pentas, ia sudah bukan menjadi dirinya sendiri, ia berubah seolah menjadi apa yang diperankannya (prajurit, ksatria, dewa, putri, raja, dsb.). Greged adalah semangat jiwa yang ada dalam diri penari yang terwujud pada karakter yang dibawakan. Sengguh adalah percaya diri yang terjaga dalam diri penari, karena karakter yang dibawakan sama dengan menyampaikan pesan pada penontonnya. Ora mingkuh adalah sifat pantang mundur, keberanian yang harus terjaga untuk tetap mantap maju ke depan (Soedarsono, 2000).

\subsubsection{Pemertahanan Keunikan Wayang Wong Gaya Yogyakarta}

Wayang wong gaya Yogyakarta disebut unik karena memiliki perbedaan dan kekhasan dibandingkan wayang wong lainnya. Pembanding terdekat adalah wayang wong dari Surakarta. Namun, secara umum, perbedaan terlihat dari panggung tempat pementasan, cara berdialog, gerakan penari, tata busana dan tata rias.

Wayang wong gaya Yogyakarta kini dapat dipentaskan di mana saja, tetapi yang khas dari panggung pementasannya adalah tidak ada dekorasi backdrop atau latar visual yang menunjukkan lokasi para pemain berada dalam suatu adegan. Karena wayang wong dilahirkan kembali dan hidup berkembang di kraton, maka konsep tokohtokoh ideal sering mengacu konteks sosialnya, yaitu pada masyarakat Jawa yang introver. Sifat tertutup tersebut muncul dalam karakter ksatria yang umumnya digambarkan berperilaku halus, bergerak lambat, tenang sehingga kadang-kadang terkesan feminin. Contohnya adalah Arjuna, Rama, Panji, Laksmana (Soedarsono dan Narawati, 2014). Bahasa yang digunakan dalam wayang wong gaya Yogyakarta berbeda dari bahasa Jawa sehari-hari dan ada lagu berbeda sesuai kelompok karakter yang dimainkan.

\section{a. Gerak dan karakter}

Pola gerak dasar wayang wong berpijak pada pola gerak wayang kulit. Pola gerak menjelaskan watak atau karakter tokoh yang dimainkan. Dengan mengamati gerakan, cara berjalan, tingkah laku, dan gaya bicara para pemain, penonton awam dapat menduga tokoh tersebut memainkan karakter halus atau keras. La Meri mengemukakan adanya dua pola gerak tubuh, yaitu simetris dan asimetris. Garis gerak yang simetris menunjukkan kesan sederhana, tenang dan kokoh, sedangkan pola gerak asimetris mengesankan kedinamisan tetapi kadang-kadang kurang kokoh (Soedarsono, 2000). Tari putra gagah, karakter Bima misalnya, pola gerak lengannya simetris sehingga menimbulkan kesan sederhana, kokoh, teguh, juga rendah hati. Watak para kurawa yang tidak baik dimunculkan dari pola gerak yang sebagian besar asimetris.

Karakter dasar wayang wong gaya Yogyakarta saat ini ada 21 tipe, yang merupakan pengembangan dari tiga tipe karakter, yaitu putra halus, putra gagah, putri. Pengembangan karakter tersebut disempurnakan pada masa Sultan Hamengku Buwono VIII (1921-1939). Karakter putri tidak berkembang, tetap satu (Soedarsono dan Narawati, 2014). Menurut penjelasan para pakar penari dan akademisi tari, sejak awal mula wayang wong dihidupkan kembali oleh Sultan Hamengku Buwono I, para putri tidak dilibatkan dalam kesenian. Mereka boleh mempelajari tari untuk kepentingan olah tubuh dan rasa tetapi tidak patut tampil ditonton banyak orang 
apalagi pria. Pembedaan posisi antara pria dan wanita di kraton sangat jelas, sehingga tidak heran terdapat istilah keputran dan keputren.

Konsep etis Jawa mengakibatkan pengotakan antara pria dan wanita, dan itu memunculkan perbedaan estetis pola gerak antara tari putri dan tari putra. Perbedaan gerak karakter putra dan putri terlihat dari penggunaan ruang gerak dan level tubuh. Karakter putri biasanya menggunakan ruang sempit dengan anggota badan berlevel rendah dan tertutup. Tari putri hampir tidak pernah mengangkat kaki dari lantai, hanya sedikit mengangkat kaki dari lantai. Fokus gerak pada lengan bawah, tangan dan kepala. Ketidakleluasaan gerak ini memberikan kesan feminin dari karakter putri (Soedarsono, 1997). Contoh karakter putri: Sumbadra, Sinta, Larasati, Srikandhi.

Setiap karakter tari putra dan putri memiliki kekhasan. Karakter putra dibedakan menjadi putra halus yang rendah hati (contohnya Yudhistira, Arjuna, Abimanyu, Rama, Laksmana, Palasara); putra halus yang aktif dan agresif (Salya, Bisma, Karna, Wibisana); putra gagah tetapi rendah hati (Werkudara, Gatutkaca, Antareja); putra gagah dan sombong (Baladewa, Suteja, Rawana); putra gagah agak rendah hati (Duryudana, Udawa); putra gagah sombong, nakal (Burisrawa, Dursasana, dan Pragota); putra gagah murid Pertapa; abdi dalam sekaligus pelawak dan penasihat (punakawan). Karakter tambahan digubah untuk para dewa, yaitu dewa dengan karakter halus dan rendah hati (Batara Wisnu, Batara Kamajaya); karakter dewa yang halus dan rendah hati (Batara Guru); dewa yang halus tetapi aktif (Batara Indra); dewa gagah tetapi rendah hati (Batara Bayu); dewa gagah dan dinamis (Batara Brama, Batara Sambu, Batara Basuki); dewa gagah dan aktif (Batara Narada). Karakter di kelompok raksasajuga dibedakan dalam gerakan berbeda untuk para raja dan pangeran raksasa yang gagah dan sombong (Prabu Niwatakawaca, Kumbakarna); raksasa gagah, kasar dan sombong (Cakil, Pragalba). Pola gerakan lain dibuat untuk karakter raja jin yang gagah, kuat serta kasar; karakter kera ksatria yang gagah dan rendah hati (Hanuman); kera ksatria yang gagah dan agresif (Subali, Sugriwa, dan Hanggada); dan, karakter prajurit Bugis yang gagah dan dinamis.

Secara ringkas, karakter putra halus bergerak dengan langkah kaki tidak lebih dari $20 \mathrm{~cm}$ dari lantai tari, tungkai agak ditekuk ke luar. Karakter rendah hati angkatan lengannya agak rendah pula. Secara semiotik, terlihat bahwa tarian putra maupun putri halus menunjukkan sifat tertutup, tidak lugas, gerakan serba tenang, tetapi jelas arahnya. Dalam dialog, suara yang digunakan pun cenderung bernada rendah, tidak lantang dan monoton. Artinya, dalam berinteraksi dengan tokoh lain pun, muncul kesan menahan diri.

Gambaran tersebut berbeda dengan karakter putra gagah yang umumnya bergerak dengan tungkai terangkat tinggi dan lengan diangkat tinggi. Secara semiotik, posisi terbuka, ruang luas untuk kaki menunjukkan tidak adanya batas, keleluasaan. Dari sisi nada suara, karakter gagah tetapi rendah hati menggunakan nada bicara rendah dan monoton, tetapi karakter yang dinamis, aktif, agresif biasanya dikenali dari nada yang melodius. Di sini terdapat kemiripan nilai. Nada rendah dan monoton menunjukkan kesan tidak banyak tingkah, tenang, tidak sombong. Nada yang melodius memang memberikan kesan sesuatu yang hidup, selalu bergerak, dan terkadang menunjukkan sifat langsung, bersuara tanpa berpikir sebelumya sehingga berpotensi mencetuskan pertikaian. Dengan demikian, ada keterkaitan antara karakter, gerakan dan suara dan nada suara.

Dapat dibayangkan persiapan yang harus dilakukan penari yang mendapat peran sesuai karakter di atas. Dari penuturan para pakar tari klasik, sekarang ini tidak mudah menemukan penari yang mampu menjiwai karakter sepenuh hati karena cara mempelajari tari pun berbeda jauh. Dahulu, selain para pangeran di kraton, penari adalah para abdi 
dalem yang memang mengabdikan waktunya untuk menjadi penari kraton dan berlatih kapan pun. Kini, siswa pebelajar tari adalah masyarakat umum yang juga memiliki kegiatannya masing-masing; belajar menari bukan untuk berprofesi sebagai penari.

\section{b. Tata Busana dan Tata Rias}

Meskipun tampak serba terbuka di bagian atas pada kebanyakan karakter putri dan putra, tata busana tersebut masih berpijak pada tata susila Jawa yang khas. Peranan putri mengenakan pakaian kain panjang yang membalut dari seluruh tubuh dari perut hingga ke kaki. Cara mengenakan kain juga agak kencang sehingga memang memberi kesan bahwa perempuan Jawa tidak pernah mengangkat kaki tinggi-tinggi, melangkah lebar, dan membuka kaki. Penari juga mengenakan sondher atau sampur, yaitu selendang panjang yang dikenakan melingkari perut lalu kedua ujungnya menjuntai menyentuh kaki. Cara pemakaian seperti itu termasuk menguatkan kefemininan penari putri karena tidak perlu membuka lebar lengannya (Soedarsono, 2000).

Karena tari Jawa berpijak pada konsep maskulin yang kuat, yang ditunjukkan dengan pola gerak yang melebar, maka diperlukan ruang gerak yang lebih bebas. Itu sebabnya penari putra menggunakan celana agak panjang yang menutupi bagian bawah mulai dari perut sampai di bawah lutut, lalu kain dililitkan menutupi perut sampai di atas lutut (supit urang). Umumnya karakter pria bertelanjang dada, kecuali karakter kera, dewa dan raksasa. Dalam konsep etika Jawa, pria bertelanjang dada adalah yang paling susila. Bahkan, dalam penggambaran yang disampaikan Soedarsono (2000), pada masa lalu, selain bangsawan dan abdi dalem, siapa saja yang akan masuk ke istana juga harus bertelanjang dada dan tanpa alas kaki. Hanya orang Belanda yang diperkenankan masuk mengenakan baju dan beralas kaki.

Ilustrasi lain tentang makna busana ditunjukkan oleh metafora pada busana. Para raksasa yang bertubuh besar dan mengenakan kaus kaki dan kaus tangan putih tetap dapat dikalahkan dari ksatria bertubuh kecil. Raksasa adalah perwujudan dari penjajah Belanda yang rata-rata berperawakan tinggi besar, sedangkan ksatria tentu saja bangsa Indonesia (Kuswarsantyo, 2018).

Selain busana, aksesori lain yang dikenakan sebagian besar karakter wayang wong adalah hiasan kepala, lengan dan kaki. Penutup kepala disebut garudha mungkur, karena hiasan garuda itu menghadap ke belakang. Menurut Soedarsono (1997), hiasan itu kemungkinan berfungsi sebagai kekuatan pelindung karena biasanya ditemukan pada karakter raja dan pangeran berwatak baik pada relief candi di Jawa Timur dan wayang kulit. Garudha mungkur di Yogyakarta juga disebut bledhegan yang secara denotatif mengacu pada guntur, kilat dan petir. Lebih lanjut, jika dikaitkan dengan legenda Jawa kuno tentang Ki Ageng Sela yang berhasil menangkap petir dan mempersembahkannya pada Sultan Demak, bledhegan ini berfungsi seperti lambang pelindung bagi hampir semua karakter. Hanya tokoh ksatria yang kuat dan rendah hati yang tidak menggunakannya, kemungkinan mereka dianggap tidak memerlukan kekuatan protektif tambahan, menurut Soedarsono (1997). Aksesori lain pada penari wayang wong adalah mekutha (mahkota seperti helm) dan praba. Praba mengacu pada lingkaran cahaya yang terdapat di belakang arca. Dalam wayang wong, praba diwujudkan berupa aksesori yang dipasang di punggung penari, penanda kebesaran. Aksesori lainnya adalah gelang kelat bahu, yang dikenakan di lengan atas para penari, sedangkan kalung sangsangan dikenakan di leher hampir setiap karakter.

Tata rias pemain wayang wong dibedakan menurut karakternya. Ada kategori karakter halus, berperawakan kecil dan langsing dan hidung mancung, mata setengah tertutup; karakter berperawakan sedang dan kuat, hidung biasa, mata biasa; karakter berperawakan tinggi, besar, serta kuat, hidung besar dan mata yang terbuka 


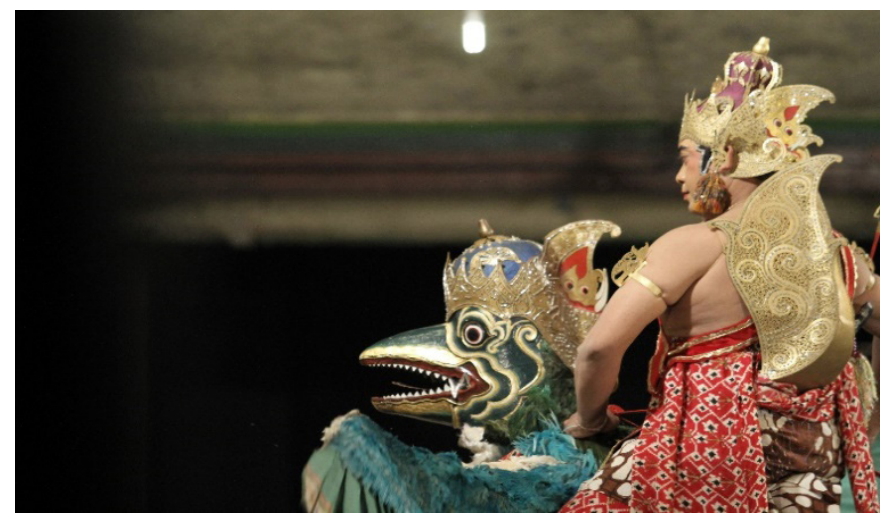

Gambar 2. Aksesori garuda mungkur dan praba (Sumber: YSAB 2018)

lebar. Alis dan kumis menjadi penting untuk membedakan masing-masing karakter. Putri tentu tidak berkumis, begitu juga dengan karakter putra halus dan rendah hati. Soedarsono (1997) menunjukkan tujuh perbedaan bentuk alis, cambang dan kumis dalam tata rias wayang wong. Semua karakter digambarkan memiliki cambang, tetapi berdasarkan pengamatan, godek atau rambut di pipi pada karakter putri digantikan dengan semacam kain gelap berhias, yang menyambung dengan mekutha. Karakter dinamis digambarkan dengan alis yang agak diukir di ujungnya dan ditarik naik ke atas, semakin tegas warnanya semakin kuat tingkat keagresifan karakter. Sama halnya dengan kumis. Ketegasan juga digambarkan dari riasan mata bagian bawah: semakin tegas, semakin menggambarkan sifat dinamis dan agresif karakter. Alis yang digambar sesuai lengkungan alis biasa menunjukkan sifat rendah hati karakter.

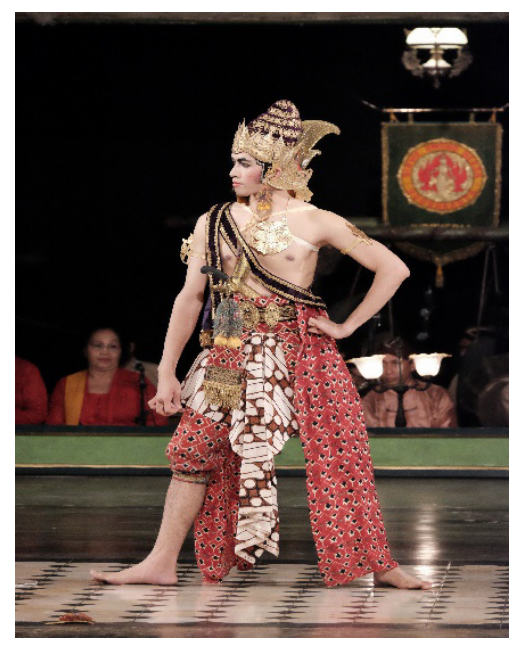

\section{Gambar 3. Penari \\ - karakter halus \\ (Sumber: YSAB \\ 2018)}

Gambar 4. Raksasa (sumber: YSAB 2018)

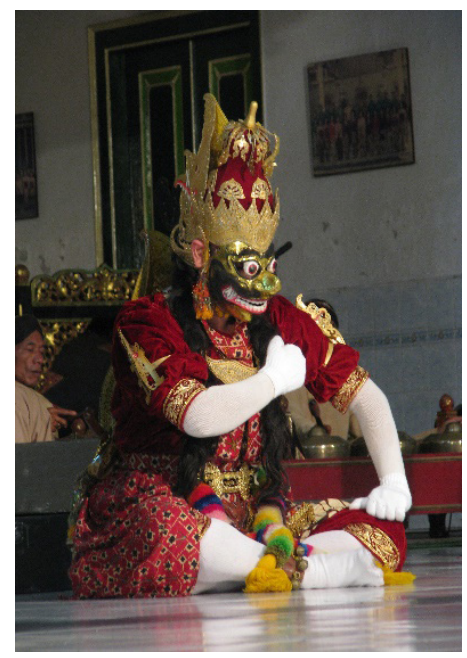

Yang dilakukan Yayasan Pamulangan Beksa Sasminta Mardawa (YPBSM), Yayasan Siswa Among Beksa (YSAB), dan Paguyuban Seni Suryo Kencono (PSSK) untuk menjaga keberadaan warisan budaya wayang wong gaya Yogyakarta adalah melalui pendidikan, pementasan, dan mengikuti event dan festival. Ketiga tempat tersebut memiliki cara pembelajaran berbeda.

YPBSM dan YSAB menerapkan sistem seperti bersekolah. Siswa mengikuti pelajaran sebanyak dua kali seminggu, masing-masing selama satu jam. Ada uang 
pangkal di awal tahun ajaran dan membayar SPP setiap bulannya, sedangkan di PSSK pembayaran dilakukan setiap kali datang belajar menari. Menurut bagian pendidikan di YSAB, siswa yang belajar tari tingkat dasar mengalami peningkatan. Hal tersebut tidak lepas dari strategi promosi YSAB yang sangat aktif melalui media sosial. Pendidikan di YPBSM dan YSAB dilakukan secara bertahap, ada tingkat dasar, tingkat menengah, dan tingkat mahir. Setiap tahap dievaluasi melalui ujian naik tingkat kemahiran. Peserta kursus bahkan ada wisatawan asing yang ingin mencicipi menari Jawa. Dalam hal ini YSAB juga memiliki program singkat yang disesuaikan dengan permintaan siswa atau wisatawan. Di akhir program singkat YSAB tersebut, siswa menari dengan didandani busana tari lengkap, mendapat sertifikat dan foto kenang-kenangan sebagai 'penari'.

YPBSM memiliki cara lain untuk menjaga keberadaan tari klasik selain program rutin pembelajaran tari, yaitu mengadakan acara kumpul bersama menari di pendopo Dalem Pujokusuman setiap hari Selasa legi tiap bulan, yang diberi nama Selasa Legen. Penari yang ikut boleh dari mana saja, siapa pun yang ingin joged bersama, tidak harus murid dari YPBSM. PSSK sering mengadakan pelatihan dan pengenalan tari klasik dan gamelan dengan peserta para siswa dari dalam dan luar kota berdasarkan pesanan.

Agar para siswa yang telah belajar menari berkesempatan menunjukkan hasil latihan dan belajarnya, ketiga tempat pembelajaran tari klasik tersebut biasanya mengadakan pementasan wayang wong dan tari klasik setiap peringatan ulang tahun mereka. Pertunjukan seperti itu diadakan di pendopo Dalem: YPSBM di Dalem Pujokusuman, YSAB di Dalem Kaneman, dan PSSK di Dalem Suryowijayan. Pementasan lain yang memerlukan persiapan serius adalah festival wayang wong gaya Yogyakarta yang didanai oleh Dana Istimewa DIY (danais) melalui dinas pemerintahan (Dinas Kebudayaan). Festival seperti itu biasanya diikuti oleh semua paguyuban tari klasik yang berada di Yogyakarta yang diundang oleh dinas pemerintahan.

Sementara ini, menurut Kuswarsantyo (2018), cara melestarikan warisan budaya tari klasik dan wayang wong gaya Yogyakarta adalah melalui 1) latihan rutin seperti yang dilakukan di ketiga tempat pembelajaran di atas; 2) penyelenggaraan pelatihan tari; dan 3) keikutsertaan dalam festival wayang wong. Dinas Pendidikan Daerah Istimewa Yogyakarta setiap tahun menyelenggarakan festival dengan mengundang enam institusi pembelajaran tari klasik gaya Yogyakarta. Sedangkan untuk kebutuhan pariwisata, yang biasa dilakukan adalah menyelenggarakan pentas paket wisata selama 90 menit yang terdiri dari pertunjukan tari klasik lepas (pethilan), istirahat/melihat karawitan, dan pertunjukan fragmen wayang wong lakon Ramayana.

\subsection{Komodifikasi Pertunjukan Wayang Wong Gaya Yogyakarta untuk Atraksi Wisata}

Soedarsono (1989/1990) berharap bahwa seni pertunjukan yang diproduksi untuk pariwisata dibuat dengan berpijak pada diagram Wimsatt yang memberikan keseimbangan antara dua domain berbeda, yaitu seni wisata yang berada di irisan antara domain seni dan domain industri pariwisata. Seni wisata adalah seni pertunjukan yang dikemas khusus sesuai dengan kebutuhan selera wisatawan. Seni pertunjukan yang disajikan bagi wisatawan tentunya disesuaikan dengan keperluan wisatawan.

Begitu wayang wong gaya Yogyakarta menjadi bagian dari pariwisata, ia perlu menyiapkan diri masuk ke dalam industri budaya. Dilihat dari asalnya, wayang wong gaya Yogyakarta berasal dari kelompok elit, yang tumbuh dari kaum ningrat di balik tembok kraton. Mengacu pada pandangan Adorno, dalam Piliang dan Jaelani (2018), wayang wong gaya Yogyakarta termasuk budaya tinggi karena 
menunjukkan standar kualitas, estetika dan selera tinggi para Sultan dan para seniman tarinya. Budaya tinggi memerlukan persiapan produksi yang serius, tidak bisa asal mengulangi, mengimitasi tampilan yang sudah ada sebelumnya. Sebagai tontonan bagi wisatawan, berarti sesuatu dilakukan untuk mendapatkan profit. Ada penyesuaian produk dengan selera pasar yang hanya punya waktu tinggal sebentar di kota Yogyakarta. Motif demi mendapat keuntungan tersebut menjelaskan bahwa industri budaya memproduksi barang secara massal lewat teknik produksi massa dan menghasilkan produk dengan 'selera massa' (selera rata-rata), yang mudah dipahami oleh massa yang luas (Piliang dan Jaelani, 2018).

Berdasarkan prinsip komodifikasi seperti itu, tercipta kategori estetika yang disebut W. F. Haug sebagai estetika komoditas. Dalam estetika komoditas bentuk estetik diciptakan berlandaskan motif daya tarik, keterpesonaan, dan perhatian massa dengan mengangkat berbagai bentuk daya pesona (fetishism) untuk memenuhi hasrat rendah (desire) manusia. Fetishism dan desire disertakan sebagai elemen estetis karena paling mudah diapresiasi, dipahami dan dicerna oleh massa yang luas tanpa memerlukan tingkat apresiasi dan analisis yang tinggi (Piliang dan Jaelani, 2018). Dalam wayang wong gaya Yogyakarta, yang disebut fetisisme dan desire sangat kecil meskipun hampir semua karakter pria bertelanjang dada dan begitu juga dengan penari putri yang berbahu terbuka. Adanya patokan baku dalam pertunjukan wayang wong menjadi pengendali sehingga produk budaya tersebut tidak luruh menjadi budaya massa yang asal-asalan, bahkan tetap berusaha menjaga keagungannya.

Diagram Wimsatt yang dikemukakan Soedarsono (1989/1990) dapat menjelaskan bahwa irisan yang berada di tengah, di antara sisi seni dan sisi industri pariwisata, adalah elemen yang adaptif dari pertunjukan wayang wong gaya Yogyakarta, yang terbuka untuk komodifikasi. Elemen tersebut adalah pemilihan lakon, durasi, tempat pementasan,

Wisatawan umumnya tidak mempunyai waktu banyak untuk menyaksikan pergelaran wayang wong secara utuh (ada goro-goro), karena satu lakon berdurasi antara dua sampai empat jam. Di kota Yogyakarta, lama tinggal rata-rata wisatawan tidak lebih dari dua hari, sementara obyek wisata yang dikunjungi banyak. Maka sebagai pertunjukan malam hari, durasi pergelaran wayang wong lah yang perlu dipangkas. Menurut Kuswarsantyo (2018), durasi pertunjukan kemasan pariwisata bisa sekitar 40 - 60 menit, tanpa adegan goro-goro. Fungsi pertunjukan menjadi pengenalan terhadap luhurnya seni pertunjukan tari dan budaya Jawa saja. Pertunjukan pun lebih cantik disaksikan pada malam hari. Cahaya lampu yang menimpa busana dan aksesori penari akan menghasilkan pendaran yang indah sehingga mengesankan.

Cerita yang dipentaskan dalam wayang kulit dan wayang wong diambil dari Mahabarata, Ramayana, Arjunasasrabau, serta mitologi Jawa seperti lakon Murwakala dan Sri Temurun. Sering juga lakon tersebut merupakan carangan, yaitu cerita yang digubah oleh dhalang, yang menyimpang dari wiracarita klasik atau cerita mitologi (Soedarsono, 1997). Lama pertunjukan wayang wong gaya Yogyakarta tergantung dari lakon yang dimainkan. Jika terlalu panjang bagi wisatawan, dilakukan fragmentasi atau pemotongan cerita.

Gunungan atau kayon, seperti dalam wayang kulit, memiliki banyak makna. Gunungan melambangkan pohon kehidupan. Gunungan juga bisa menjadi tanda waktu awal dan akhir pertunjukan, juga bisa mewakili hutan, istana, gunung, api, angin, pertapaan, atau tempat lainnya. Dari pementasan yang diamati, kayon dibawakan oleh beberapa penari yang bergerak kian kemari. Kemudian, dari kothak, 
para penari berjalan menuju lantai pentas dalam kondisi siap memasuki karakter yang dibawakan. Sebelum naik ke lantai pentas, ia harus melakukan sembah, baru naik dalam posisi berjongkok, berjalan dengan posisi jongkok menuju titik tempat akan mulai menari. Dari posisi jongkok akan duduk bersila, ia harus melakukan sembah lagi. Saat ini penari sudah harus konsentrasi penuh. Pada adegan perang, posisi persiapan tidak selalu harus duduk bersila tetapi langsung ke posisi jongkok atau jengkeng. Setelah selesai menari, ia kembali ke pinggir pentas dengan posisi jengkeng lagi dan sebelum meninggalkan pentas, kembali harus melakukan sembah seperti pada permulaan akan menari. Gerakan menyembah ini memiliki makna menghormati Sultan sebagai penonton utama, meskipun beliau tidak ada di tempat. Ada juga pendapat bahwa sembah dilakukan ke hadapan Tuhan YME sebagai pendahuluan dari tari yang akan dibawakan (Soedarsono, 2000).

Pertunjukan wayang wong dalam pariwisata budaya di kota Yogyakarta, menurut kategori Murphy dan Boyle dalam Damanik (2013), adalah produk primer dalam pariwisata budaya perkotaan. Produk sekunder dalam pariwisata budaya mencakup kuliner, belanja dan fasilitas pasar. Produk kondisional atau tersier meliputi aksesibilitas, parkir, informasi, tanda (signage), dan pemandu. Ketiga kategori produk pariwisata budaya ini berada dalam ruang lingkup masyarakat. Dari wawancara dan pengamatan di ketiga lokasi penelitian dapat dikatakan bahwa wayang wong gaya Yogyakarta saat ini belum disiapkan sepenuhnya sebagai atraksi pariwisata yang rutin. Namun, ketiga tempat pembelajaran tari klasik gaya Yogyakarta tersebut pernah mengadakan pertunjukan bagi wisatawan dengan bentuk berbeda.

Yayasan Pamulangan Beksa Sasminta Mardawa (YPBSM) mengadakan pertunjukan dengan paket kemasan wisata sejak tahun 1981 sampai tahun 1991, lalu tahun 1991-2006 di Dalem Pujokusuman sebanyak tiga kali seminggu. Tiket dijual seharga Rp50.000. Bentuk paket pementasannya terdiri dari komposisi 30 menit tarian lepas (golek, klana topeng, srimpi, dan sejenisnya), 15 menit istirahat diisi dengan pertunjukan karawitan, dan 45 menit wayang wong dengan fragmen Ramayana. Pertunjukan tersebut tidak diselingi makan malam. Menurut pihak YPBSM, pertunjukan rutin ini terhenti dan tidak berlanjut setelah bencana gempa Yogyakarta tahun 2006. Kelompok Yayasan Siswa Among Beksa (YSAB) tidak menyediakan pertunjukan rutin bagi wisatawan, tetapi memiliki program pendek yang bersifat rekreatif sekaligus edukatif bagi wisatawan yang ingin belajar menari dalam waktu singkat serta berfoto sebagai penari. Yayasan Siswa Among Beksa kadang-kadang mengadakan pertunjukan wayang wong dengan fragmen Ramayana di pendopo Dalem Kaneman bagi wisatawan atas undangan atau permintaan pihak Dalem Kaneman. Kelompok lain, Paguyuban Seni Suryo Kencono (PSSK) tidak memiliki program pertunjukan rutin yang dijual untuk wisatawan, tetapi sering mengadakan workshop tari dan gamelan dengan waktu sesuai permintaan. Materinya adalah pengenalan terhadap seni tari klasik gaya Yogyakarta dan gamelan. Yang pernah melakukan kunjungan belajar di PSSK misalnya siswa SD Amerika dan sekolah-sekolah dari Jakarta. Lakon yang umum dipentaskan di ketiga tempat tersebut adalah fragmen Ramayana.

Ketiga tempat penelitian tersebut mengakui bahwa untuk mengadakan pergelaran wayang wong secara mandiri memerlukan dana besar. Pementasan wayang wong biasanya ada jika ada pendukung dana. Sementara ini, pemerintah adalah rekan yang mendukung keberadaan paguyuban tari tersebut sekaligus sponsor utama pertunjukan. 
Ketika masih merupakan pertunjukan ritual kraton, pementasan wayang wong dilakukan di tratag Bangsal Kencana atau Pagelaran. Kini, pementasan untuk keperluan pertunjukan pariwisata dilakukan di pendopo-pendopo Dalem dan, menurut pakar tari, pendopo merupakan tempat pentas paling cocok karena memunculkan suasana tradisional Jawa. Ketika wayang wong gaya Yogyakarta dipentaskan di panggung atau di jalan sebagai street art, nilai keagungan yang diusung oleh gaya Yogyakarta berubah menjadi sekadar gerakan teknik tari yang menarik.

Wayang wong gaya Yogyakarta memang berbeda dari gaya Surakarta. Dari hal tempat pementasan saja, panggung pentas wayang wong gaya Yogyakarta terkesan sederhana, tidak rumit karena tidak memerlukan latar gambar (backdrop) yang berganti-ganti.

\section{PENUTUP}

Pergelaran wayang wong gaya Yogyakarta sebagai warisan budaya selalu berkiblat pada aturan dasar kebakuan dalam hal gerak tari, tata pentas, tata busana, tata rias termasuk iringan gamelannya karena masing-masing unsur memiliki makna tersendiri, yang mewakili keunikan dari gaya Yogyakarta.

Wayang wong gaya Yogyakarta mengalami komodifikasi ketika menjadi industri budaya sebagai atraksi wisata. Sutradara dan masyarakat kelompok tari harus bersedia mereduksi waktu, memotong gerak dalam fragmen, mengatur ulang jumlah pemain, serta persoalan teknis pementasan lain yang perlu disesuaikan dengan keinginan penyelenggara, termasuk lokasi pementasannya. Masuknya wayang wong gaya Yogyakarta dalam sistem pariwisata sebagai atraksi menimbulkan kekhawatiran akan terjadi eksploitasi dan penurunan kualitasnya, tetapi ternyata masyarakat tetap memertahankan keaslian dan keunikannya.

Dari paparan di atas dapat dikatakan bahwa 1) dibutuhkan proses dan ketekunan untuk menjadi penari wayang wong, 2) acara pementasan rutin masih jarang ada, 3) masyarakat bergantung pada dana pemerintah dan ajakan pemerintah untuk mementaskan wayang wong.

\section{DAFTAR PUSTAKA}

Ardhanari Performing Arts Studio and Management, 2014. Tayungan, diakses dari 0 , diakses tanggal 10 April 2018.

Gusti, 2015, “Teliti Wayang Wong Kraton, Dosen ISI Yogyakarta Raih Doktor". Liputan Berita UGM, diakses dari https://ugm.ac.id >berita>9674 tanggal 10 April 2018.

Holt, C., 1967. Melacak Jejak Perkembangan Seni di Indonesia, terjemahan Soedarsono (2000) Art in Indonesia: Continuities and Change. Bandung: Arti Line.

Hughes-Freeland, F., 1993. "Packaging dreams. Javanese perceptions of t o u r is m and performance" Tourism in South-East Asia/edited by Michael Hitchcock, Victor T. King and Michael J.G. Parnwell, 138-154, London: Routledge.

Indrawati, N., et.al,. 2008. "Makna Filosofi dan Nilai-nilai Yang Terkandung dalam Tari Klana Raja Gaya Yogyakarta”, Pelita, Volume III, Nomor 1, April 2008, 3-11, Yogyakarta: Universitas Negeri Yogyakarta.

Kuswarsantyo, n.d., "Materi Kuliah Tari Yogyakarta I", diakses dari https://www. google.co.id/search?, tanggal 3 November 2016. 
Nuryani, Wenti. 2004. Diktat Teknik Tari. Yogyakarta: Jurusan Seni Drama Tari dan Musik, Prodi Seni Tari, FBS Universitas Negeri Yogyakarta.

Piliang, Y.A. dan Jaelani, J. Teori Budaya Kontemporer, Penjelajahan Tanda dan Makna. Yogyakarta: Aurora.

Saearani, M.F.T., 2014. Peran Kraton Ngayogyakarta Hadiningrat Dan Institusi Pendidikan Tari dalam Proses Pewarisan Wayang wong Gaya Yogyakarta. Disertasi: Sekolah Pascasarjana UGM, Yogyakarta.

Sholihah, Amirul. 2008. Makna Filosofis Punakawan dalam Wayang Jawa (Lakon Wahyu Makutharama). Skripsi. Jogjakarta: Fakultas Ushuluddin Universitas Islam Negeri Sunan Kalijaga, diakses dari https://scholar.google.co.id tanggal 3 Februari 2018.

Soedarsono. 1989/1990. Seni Pertunjukan Jawa Tradisional dan Pariwisata di Daerah Istimewa Yogyakarta. Yogyakarta: Departemen Pendidikan dan Kebudayaan. . 1997. Wayang Wong, Drama Tari Ritual Kenegaraan di Keraton Yogyakarta. Yogyakarta: Gadjah Mada University Press. . 2000. Wayang Wong Gaya Yogyakarta. Masa Gemilang dan Memudar. Seri Pustaka Keraton Nusantara 3, Yogyakarta: Tarawang. . 2010. Seni Pertunjukan Indonesia di Era Globalisasi. Yogyakarta: Gadjah Mada University Press.

Soedarsono dan Narawati, T. 2014. Dramatari di Indonesia, Kontinuitas dan Perubahan, Yogyakarta: Gadjah Mada University Press.

Suwito, Y.S., 2005, Pelestarian Warisan Budaya Jawa dan Lingkungan Hidup untuk mendukung Industri Pariwisata di DIY. Makalah: Simposium "Lingkungan Hidup dan Pariwisata". Yogyakarta.

Sri Sultan Hamengku Buwono, diakses dari kratonjogja.id/raja-raja karaton Ngayogyakarta hadiningrat, tanggal 13/04/2018

\section{Sumber Lisan}

Kuswarsantyo (KRT Condrowaseso), 2018

Dosen tari klasik gaya Yogyakarta dan seni pertunjukan, Universitas Negeri Yogyakarta dan Pimpinan Sanggar Tari Condroradono, jalan Kadipaten Kidul, Yogyakarta, Januari 2018

R.M. Dinusatomo (KPH Pujoningrat/ Kanjeng Pujan), 2017.

Yayasan Siswa Among Beksa, jalan Kadipaten Wetan, Yogyakarta, November 2017.

Sri Kadaryati (Nyi KRT Kusumoningrat), 2017. Paguyuban Suryokencono, Dalem Suryowijayan, jalan Suryowijayan, Yogyakarta, November 2017 dan Maret 2018. Siti Sutiyah (Nyi KRT Dwijo Sasminto Murti) , 2017, Yayasan Pamulangan Beksa Sasminta Mardawa, Dalem Pujokusuman, jalan Brigjen Katamso, Yogyakarta, Desember 2017 dan Maret 2018. 